\title{
THE MORAL AND RELIGIOUS CHARACTER OF ABRAHAM LINCOLN.
}

\author{
JOHN R. SAMPEY, D.D., LL.D.
}

Abraham Lincoln was born in a log cabin in the backwoods of Kentucky, February 12, 1809. His parents were quite poor and illiterate. When Abraham was seven years old his father moved to Indiana. The next year the boy's mother died. Two years later his father married Sally Bush Johnston, a widow with three children. The stepmother brought some worldly goods to the Indiana cabin, and, better still, a kind heart and generous interest in her new son. Abraham went to several schools for a few weeks at a time during his youth. Writing in 1860 , the candidate for the presidency of the United States says of himself, "Abraham now thinks that the aggregate of all his schooling did not amount to one year." His stepmother testifies of Abe: "He read every book he could lay his hands on; and when he came across a passage that struck him, he would write it down on boards, if he had no paper, and keep it there until he did get paper. Then he would rewrite it, look at it, repeat it. He had a copy-book, a kind of scrap-book, in which he put down all things, and thus preserved them." The future orator and writer of state papers thus put himself in training for his life work. The list of books accessible in a backwoods settlement was not long-"Robinson Crusoe", Aesop's "Fables", Bunyan's "Pilgrim's Progress", Weems's "Life of Washington", and a "History of the United States". The Revised Statutes of Indiana also claimed his attention, and it is probable that he also had access to the Bible.

Abraham early learned to swing an axe, his tall form and long arms giving him ability to surpass his associates in the use of this tool so necessary in backwoods life. He was an expert rail-splitter. When Abraham was nineteen he made a trip as a hired hand on a flatboat to New Orleans. He also did 
service as a clerk in a country store at Gentryville. Nicolay describes him as possessing "quick intelligence, ready sympathy, a cheerful temper, a kindling humor, a generous and helpful spirit. He was both a ready talker and an appreciative listener. By virtue of his tall stature and unusual strength of sinew and muscle, he was from the beginning a leader in all athletic games; by reason of his studious habits and his extraordinarily retentive memory, he quickly became the best storyteller among his companions". He was almost entirely free from the vices of the rough society by which he was surrounded, neither drinking nor swearing nor fighting. He did not even chew and smoke. An occasional oath, under great excitement, fell from his lips both in early and later life, and his stories sometimes contained vulgar expressions.

In a brief autobiographical sketch Mr. Lincoln writes: "March 1, 1830, Abraham having just completed his twentyfirst year, his father and family, with the families of the two daughters and sons-in-law of his stepmother, left the old homestead in Indiana and came to Illinois. Their mode of conveyance was wagons drawn by ox-teams, and Abraham drove one of the teams." The family settled on the north side of the Sangamon River about ten miles west of Decatur.

In 1831 young Lincoln made a second trip to New Orleans on a flatboat. In New Orleans he witnessed the sale of a negro at public auction. As he turned away from the revolting scene, Lincoln remarked to his companion, "If I ever get a chance at that thing, I'll hit it hard".

In 1832 Loncoln announced himself as a candidate for the State Legislature. The letter which he published in the county paper contains the following avowal of his hopes and aims in life: "Every man is said to have his peculiar ambition. Whether it be true or not, I can say, for one, that I have no other so great as that of being truly esteemed of my fellowmen by rendering myself worthy of their esteem. How far I shall succeed in gratifying this ambition is yet to be developed. I am young, and unknown to many of you. I was born, and have ever remained, in the most humble walks of life. I have no wealthy or popular relations or friends to recommend me. 
My case is thrown exclusively upon the independent voters of the country, and if elected they will have conferred a favor upon me for which I shall be unremitting in my labors to compensate. But if the good people in their wisdom shall see fit to keep me in the background, I have been too familiar with disappointments to be very much chagrined." The young man of twenty-three already knew how to put his case with skill before his constituency. Though defeated in his first political contest, Lincoln received a large vote, and in his home precinct lacked but three votes of securing unanimous support.

About this time Lincoln formed a partnership with a. man named Berry in the conduct of a village store. The business was unsuccessful, and Lincoln found himself pretty heavily in debt. He had already won a reputation for honesty, and he kept it by the manly way in which he finally paid all his notes with interest. It took him seventeen years to pay off what he was accustomed to call the "national debt". Thus he earned the title of "Honest old Abe", which proved to be a valuable asset in his political career.

In 1833 Lincoln was offered a position as deputy surveyor of Sangamon county. "He accepted, procured a compass and chain, studied Flint and Gibson a little, and went at it. This procured bread, and kept soul and body together." $\mathrm{He}$ also served as postmaster of New Salem.

In 1834 Lincoln was elected to the Legislature by a vote that was quite flattering to the young politician. He thus describes his entrance into the profession of the law: "Major John T. Stuart, then in full practice of the law, was also elected. During the canvass, in a private conversation, he encouraged Abraham to study law. After the election, he borrowed books of Stuart, took them home with him, and went at it in good earnest. He studied with nobody. **** In the autumn of 1836 he obtained a law license, and on April 15, 1837, removed to Springfield and commenced to practice, his old friend Stuart taking him into partnership."

For nearly a quarter of a century Lincoln practiced law in the courts of Illinois, toward the close of the period being recognized as a lawyer of the first rank. He was a member of 
the State Legislature for eight years, represented his district in Congress two years, and was twice elected President of the United States.

During his service in the Legislature some resolutions were passed on the subject of slavery which Lincoln could not endorse. He and his colleagues entered a formal protest on the journals of the House, in the course of which they describe their attitude as follows: "They believe that the institution of slavery is founded on both injustice and bad policy, but that the promulgation of abolition doctrines tends rather to increase than abate its evils." From the beginning to the end of his public career Lincoln was a foe to slavery as an institution, but he was always conservative in his speech and actions. He hated slavery, but he revered the Constitution, and refused to override the constitutional rights of the slave States. Finally the law of military necessity came to the aid of his conviction that slavery was wrong per se, and he wrote his Emancipation Proclamation. It may be of interest to the reader to see some of Mr. Lincoln's more notable utterances on the great issue that finally plunged the country into civil war.

June 26, 1857, in a speech on the Dred Scot decision in reply to Stephen A. Douglas, Mr. Lincoln said: "Now I protest against the counterfeit logic which concludes that because $I$ do not want a black woman for a slave I must necessarily want her for a wife. I need not have her for either. I can just leave her alone. In some respects she certainly is not my equal; but in her natural right to eat the bread she earns with her own hands without asking leave of anyone else, she is my equal and the equal of all others."

In the famous debates with Douglas in 1858 Lincoln remarked: "I say, then, that there is no way of putting an end to the slavery agitation amongst us, but to put it back upon the basis where our fathers placed it, no way but to keep it out of our new Territories-to restrict it forever to the old States where it now exists. Then the public mind will rest in the belief that it is in the course of ultimate extinction. That is one way of putting an end to the slavery agitation. The 
other way is for us to surrender and let Judge Douglas and his friends have their way and plant slavery over all the States; cease speaking of it as in any way wrong; regard slavery as one of the common matters of property and speak of negroes as we do of our horses and cattle."

In a letter to Pierce and others, on April 6, 1859, these strong words occur: "This is a world of compensation; and he who would be no slave must consent to have no slave. Those who deny freedom to others deserve it not for themseives; and, under a just God, cannot long retain it."

Later in the same year Mr. Lincoln spoke twice in Ohio in reply to Mr. Douglas. From these addresses we select the following quotations: "Now, what is Judge Douglas's popular sovereignty? It is as a principle no other than that, if one man chooses to make a slave of another man, neither that other man nor anybody else has a right to object." In the same campaign in Ohio in $1859 \mathrm{Mr}$. Lincoln gave expression to the following conservative views: "I say we must not interfere with the institution of slavery in the States where it exists, because the Constitution forbids it, and the general welfare does not require us to do so. We must not withhold an efficient fugitive-slave law, because the Constitution requires us, as I understand it, not to withhold such a law. But we must prevent the outspreading of the institution, because neither the Constitution nor the general welfare requires us to extend it. We must prevent the revival of the African slave trade, and the enacting by Congress of a Territorial slave code. We must prevent each of these things being done by either congresses or courts. The people of these United States are the rightful masters of both congresses and courts, not to overthrow the Constitution, but to overthrow the men who pervert the Constituion."

In his famous Cooper Institute Speech, on February 27, 1860, Mr. Lincoln still stood as the leading conservative opponent of slavery. He merely wished to keep it from spreading beyond the existing slave States. "Wrong as we think slavery is, we can yet afford to let it alone where it is, because that much is due to the necessity arising from its actual pres- 
ence in the nation; but can we, while our votes will prevent it, allow it to spread into the national Territories, and to overrun us here in the free States?" The closing sentence of this great address is an index to the author's moral manhood: "Let us have faith that right makes might, and in that faith, let us, to the end, dare to do our duty as we understand it."

In his Inaugural Address, on March 4, 1861, President Lincoln states the main issue between the North and the South in a single sentence: "One section of our country believes slavery is right and ought to be extended, while the other believes it is wrong and ought not to be extended; that is the only substantial dispute." Addressing the men of the South, he laid upon them the responsibility of choosing war or peace: "In your hands, my dissatisfied fellow-countrymen, and not in mine, is the momentous issue of civil war. The government will not assail you. You can have no conflict without being yourselves the aggressors." With rare diplomacy he threw upon the South the onus of precipitating war by the attack upon Fort Sumter.

President Lincoln preferred to overthrow slavery in constitutional ways and with full remuneration to the slave owners. Gradual emancipation would have satisfied him fully, and in this policy he would probably have received the support of a majority of the people in the free States. But war broke out, and emancipation became a military necessity if the Union was to be preserved. In the earlier stages of the war Lincoln still advocated the policy of gradual emancipation. As late as March 6, 1862, in a special message to Congress he recommended the adoption of the following joint resolution: "Resolved, That the United States ought to co-operate with any State which may adopt gradual abolishment of slavery, giving to such State pecuniary aid, to be used by such State, in its discretion, to compensate for the inconveniences, public and private, produced by such change of system." For some months President Lincoln did all that he could to secure in the border States that had not left the Union the acceptance of the policy of the gradual and compensated abolition of slavery. On July 22,1862 , having become convinced that eman- 
cipation was a military necessity, President Lincoln notified his cabinet of his purpose to issue a proclamation setting free on January 1, 1863, all persons held as slaves in States not recognizing the constitutional authority of the United States. He decided to wait until a Union victory should be won before issuing the proclamation. Meantime, Horace Greeley and others thought that the President was moving too slowly and without any definite policy. In reply to an open letter from Mr. Greeley, President Lincoln wrote on August 22, 1862 : "If there be those who would not save the Union unless they could at the same time save slavery, I do not agree with them. If there be those who would not save the Union unless they could, at the same time destroy slavery, I do not agree with them. My paramount object in this struggle is to save the Union, and is not either to save or to destroy slavery. If I could save the Union without freeing any slave, I would do it; and if I could save it by freeing all the slaves, I would do it; and if I could save it by freeing some and leaving others alone, I would also do that. What $I$ do about slavery and the colored race, I do because I believe it helps to save the Union; and what I forbear, I forbear because I do not believe it would help to save the Union." If all this seems to imply a lack of interest in the freedom of the slaves, the correction of such a false inference is to be found not only in Mr. Lincoln's general course from 1857 to 1862 , but also in the closing sentence of his letter to Mr. Greeley: "I have here stated my purpose according to my view of official duty; and I intend no modification of my oft-expressed personal wish that all men everywhere could be free."

The author of this paper, as an ardent Southerner, grew up with the notion that Mr. Lincoln was somewhat vacillating on the subject of slavery. Recent research has convinced him that this notion was erroneous. Mr. Lincoln was a great lawyer with a great reverence for the Constitution. He could not easily get his consent to advocate a policy that involved the slightest infringement of the rights of the old slave States. $\mathrm{He}$ was throughout his life a friend of freedom and a foe to slavery. He desired to help forward the movement to confine 
slavery strictly within the limits of the old slave States and finally to eliminate it from the nation by constitutional means. He tried to introduce during the war the policy of gradual and compensated abolition of slavery. At length he became convinced that instant and complete emancipation was a military necessity, if the Union was to be preserved. Hence he assumed the responsibility of setting free the slaves in the States that refused to recognize the authority of the United States. He stood ready toward the close of the great struggle to recommend compensation to the owners of slaves even in the States that had seceded. As late as February 5, 1865, when it was clear to the thinking men on both sides that the armies of the South could not long keep the field against the overwhelming forces arrayed against them,.President Lincoln convened his cabinet and read to them the draft of a joint resolution and proclamation, offering the Southern States four hundred million dollars, on condition that hostilities cease by the first of April, 1865; this sum to be paid in six per cent government bonds, pro rata on their slave population as shown by the census of 1860-one-half on April 1, the other half only on condition that the Thirteenth Amendment, abolishing slavery, be ratified by the requisite number of States before July 1, 1865. The members of the cabinet unanimously opposed the generous and humane recommendation of the noble President.

The moral character of Abraham Lincoln expressed itself in its strength and beauty in his relation to slavery. He was sane and humane and fair in his attitude to this greatest moral issue of his time. Justice and mercy stood on his right and on his left as guardian angels throughout the stormy years in which this issue was fought to a finish. Had he been morally weak, no amount of intelligence could have saved him from shipwreck. "Honest Abe" steered the ship of state safely through the rocks and shallows.

With all his greatness, Mr. Lincoln had some defects of which the world has heard much. William H. Herndon, his law partner for twenty years, has written frankly as to Lincoln's domestic troubles and other matters about which the 
outside world naturally knew little. The strange combination of melancholy with wit and humor receives much illustration in his Life of Lincoln. "Lincoln's melancholy", says Herndon, "never failed to impress any man who ever saw or knew him. The perpetual look of sadness was his most prominent feature". Herndon quotes one of Lincoln's colleagues in the Legislature of Illinois as saying that his mental depression became so intense at times that he never dared to carry a pocket knife. According to Mr. Herndon, "Two things greatly intensified his characteristic sadness: one was the endless succession of troubles in his domestic life, which he had to face in silence; and the other was unquestionably the knowledge of his own obscure and lowly origin. The recollection of these things burned a deep imprèss on his sensitive soul." Those who saw Mr. Lincoln's sad face during the dark days of the Civil War naturally ascribed the look of melancholy to the trials incident to that great struggle, but this morbid melancholy manifested itself before he was thirty-five, and seemed to be ingrained in his nature. Herndon states it as his opinion that Lincoln did not know what real joy was for many years.

How could such rich, broad humor keep house with sombre melancholy? Here we are face to face with one of the many antitheses in Lincoln's character. He was the best story-teller in the land, and laughed loudly at a good joke, whether told by himself or another. His warm friend and associate at the bar, Leonard Swett, has given an explanation of Lincoln's use of vulgar stories that commends itself as quite reasonable. "His love of fun," says Mr. Swett, "made him overlook everything else but the point of the joke sought after. If he told a good story that was refined and had a sharp point, he did not like it any better because it was refined. If it was outrageously vulgar, he never seemed to see that part of it; if it had the sharp ring of wit, nothing ever reached him but the wit. Almost any man that will tell a vulgar story has, in a degree, a vulgar mind; but it was not so with him; with all his purity of character and exalted morality and sensibility, which no man can doubt, when hunting for wit he had no ability to discriminate between 
the vulgar and the refined substances from which he extracted it. It was the wit he was after, the pure jewel, and he would pick it up out of the mud or dirt just as readily as he would from a parlor table."

To the general public Lincoln seemed to be a guileness and unsophisticated man, while those who knew him best became increasingly aware of his marvelous tact and discrimination. Mr. Swett describes how he handled men like pieces on a chessboard. "He always told enough only of his plans and purposes to induce the belief that he had communicated all, yet he reserved enough to have communicated nothing. He told all. that was unimportant with a gushing frankness, yet no man ever kept his real purposes closer, or penetrated the future further with his deep designs." Mr. Swett justly praises Mr. Lincoln's skill in holding the discordant elements in the country together, and boldly calls him a "trimmer". "Halifax, who was great in his day as a trimmer, would blush by the side of Lincoln; yet Lincoln never trimmed in principles, it was only in his conduct with men. He used the patronage of his office to feed the hunger of these various factions. Weed always declared that he kept a regular account-book of his appointments in New York, dividing his various favors so as to give each faction more than it could get from any other source, yet never enough to satisfy its appetite." We must do President Lincoln the justice to remind ourselves that he lived before the days of Civil Service Reform, and also that he deplored the scramble for office during his administration.

All the world knows that Lincoln had a kind heart. He loved kindness. He would strain a point to save some poor fellow's life. His friend from whom we have already frequently quoted relates the following incident: "I remember one day being in his room when he was sitting at his table with a large pile of papers before him, and after a pleasant talk he turned abruptly and said, 'Get out of the way, Swett, to-morrow is butcher-day, and I must go through these papers and see if I cannot find some excuse to let these poor fellows off.'" The pile of papers before him was the records of men condemned to be shot the next day, and he was trying to find some excuse to pardon many of them. 
Lincoln admitted few men to the inner circle of real friendship. Some of his supporters thought he was ungrateful, but they were as a rule office-seekers whom he could not conscientiously appoint. Lincoln never forsook a friend.

It has been well said that he was a very poor hater. $\mathrm{He}$ never removed a man because he was his personal enemy. He lived up to the high standard he set for his countrymen in his second Inaugural - "with malice toward none; with charity for all." He never learned to hate the South, nor did he hate Jefferson Davis. His ethical life was high and true. He tried to do good to his enemies. In his death the South lost her best friend north of the Potomac.

His domestic unhappiness was due to incompatibility of temperament and breeding. He was true to his unfortunate wife, and tried to conceal from the world her acts of indiscretion and temper. Well might she pronounce him "the best man that ever lived". Both in his private and in his public life Lincoln stands high in his moral manhood. There were a few excrescences on the surface of the giant oak, but its heart was sound.

When Mrs. Lincoln once reminded her husband of the idle gossip that Seward was the power behind the throne, he replied: "I may not rule myself, but certainly Seward shall not. The only ruler I have is my conscience-following God in itand these men will have to learn that yet." We may accept at its face value, as expressing the mature conclusion of a lifetime, Mrs. Lincoln's testimony: "As to his nature, he was the kindest man, most tender husband, and loving father in the world."

But what of Abraham Lincoln's religious character? Was he a Christian?

In his early life he read with avidity infidel books and imbibed much hurtful teaching. He even wrote a paper attacking the Bible and orthodox Christianity. A wise friend thrust Lincoln's manuscript into the stove, and persuaded him to quit publishing abroad his infidelity.

Lincoln tried to go to the bottom of every subject, religious as well as political. He leaned upon reason, and found it hard 
to accept any doctrine as true until he could thoroughly understand it in all its relations.

Lincoln's first partner in law says: "He was an avowed and open infidel, and sometimes bordered on atheism. ***** Lincoln always'denied that Jesus was the Christ of God-denied that Jesus was the Son of God as understood and maintained by the Christian Church."

Another of Lincoln's early friends testifies that he would read a chapter from the Bible and then argue against it in the presence of his friends.

Judge David Davis says: "The idea that Lincoln talked to a stranger about his religion or religious views, or made such speeches or remarks about it as are published, is to me absurd. I knew the man so well; he was the most reticent, secretive man I ever saw or expect to see. He had no faith, in the Christian sense of the term-had faith in laws, principles, causes and effects."

Herndon quotes at length from a statement made September 22,1870 , by Jesse W. Fell, to whom Lincoln seems to have revealed many of his religious views. Mr. Fell says: "If there were any traits of character that stood out in bold relief in the person of Mr. Lincoln they were those of truth and candor. He was utterly incapable of insincerity or professing views on this or any other subject he did not entertain. Knowing such to be his true character, that insincerity, much more duplicity, were traits wholly foreign to his nature, many of his old friends were not a little surprised at finding in some of the biographies of this great man statements concerning his religious opinions so utterly at variance with his known sentiments. True, he may have changed or modified these sentiments after his removal from among us, although this is hardly reconcilable with the history of the man, and his entire devotion to public matters during his four years' residence at the national capital. It is possible, however, that this may be the proper solution of this conflict of opinions; or it may be that, with no intention on the part of any one to mislead the public mind, those who have represented him as believing in the popular theological views of the times may have misapprehended him, as expe- 
rience shows to be quite common where no special effort has been made to attain critical accuracy on a subject of this nature. This is the more probable from the well-known fact, that Mr. Lincoln seldom communicated to any one his views on this subject; but be this as it may, I have no hesitation whatever in saying that, whilst he held many opinions in common with the great mass of Christian believers, he did not believe in what are regarded as the orthodox or evangelical views of Christianity."

"On the innate depravity of man, the character and office of the great Head of the Church, the atonement, the infallibility of the written revelation, the performance of miracles, the nature and design of present and future rewards and punishments (as they are popularly called), and many other subjects he held opinions utterly at variance with what are usually taught in the Church. I should say that his expressed views on these and kindred topics were such as, in the estimation of most believers, would place him outside the Christian pale. Yet, to my mind, such was not the true position, since his principles and practices and the spirit of his whole life were of the very kind we universally agree to call Christian; and I think this conclusion is in no wise affected by the circumstance that he never attached himself to any religious society whatever."

"His religious views were eminently practical, and are summed up, as I think, in these two propositions: the Fatherhood of God and the brotherhood of man. He fully believed in a superintending and overruling Providence that guides and controls the operations of the world, but maintained that law and order, and not their violation or suspension, are the appointed means by which this Providence is exercised."

Mr. Fell calls attention to the fact that Lincoln read a good deal in the writings of W. E. Channing and Theodore Parker. He thinks that Mr. Lincoln's religious views coincided in great measure with those of the famous Unitarian divine, Theodore Parker.

The last witness to whom we invite attention is Mrs. Lincoln herself, who says: "Mr. Lincoln had no faith and no hope in the usual acceptation of those words. He never joined a Church; 
but still, as I believe, he was a religious man by nature. $\mathrm{He}$ first seemed to think about the subject when our boy Willie died, and then more than ever about the time he went to Gettysburg; but it was a kind of poetry in his nature, and he was never a technical Christian."

At certain great crises in the national life Mr. Lincoln distinctly and clearly invoked the blessing of Almighty God upon his efforts to save the Union. The Christian reader would not for a moment suspect that the great President had the slightest doubt as to the personality of God; and yet Mr. Herndon, his partner in law for twenty years, tells us that as late as $1854 \mathrm{Mr}$. Lincoln asked him to erase the word God from a speech he had written and read to him for criticism, because his language indicated a personal God, whereas Mr. Lincoln in-. sisted no such personality ever existed. We may well question the continued existence of any such notion in the mind of Mr. Lincoln. Mr. Herndon was not much in the company of Mr. Lincoln during the four years of the Civil War. As Mrs. Lincoln intimates, Mr. Lincoln's mind was led to fresh consideration of religious questions by the death of his boy Willie and the crisis in the struggle for the preservation of the Union. Moreover, Mr. Lincoln was brought into close and sympathetic relations with many noble Christian men and women during those years of trial; and he could not fail to see the beauty and strength of Christian character when subjected to the severest strain. He was perfectly sincere when he encouraged Christian men and women to pray for him personally and for the success of the Unoin armies. He came to believe in prayer, and this would seem to imply faith in the personality of God. He did justly and loved kindness, and we may conclude, without doing violence to any known facts, that he was learning to walk humbly with his God. Perhaps no man can register exactly the stage in the religious life he had attained when the assassin's bullet suddenly robbed the nation of his inestimable services. 